\title{
FEASIBILITY STUDY OF COOLING AND PACKING STATION OF HORTICULTURAL EXPORT IMPROVEMENT ASSOCIATION (HEIA) IN LUXOR GOVERNORATE
}

(Received: 8.9.2019)

\author{
By \\ A. A. Abdul Aziz and W. Y. Sallam \\ Agriculture Economics Department, Faculty of Agricultural, Cairo University, Giza, Egypt
}

\begin{abstract}
Cold storage projects are important because they provide marketing services through sorting, grading and packing the crops. The Horticultural Export Improvement Association (HEIA) implemented new investments financed by USAID for the development of the cooling station and training district at Luxor Governorate in Upper Egypt with a storage capacity of 90 metric tons per day at L.E. 30 million investments. The Packing and Cooling Station was initiated in July 2015.

The study reflects problem at the Cooling and Packing Station at Luxor Governorate. It does not operate at its maximum capacity of 50 tons per day. It operates for no more than two months and is currently inefficiently operating where the fees are higher compared to competitors. This is due to the lack of horticultural crops to operate.

The objectives current study were to study the actual reality of the nine associations producing and marketing horticultural crops at Luxor and Qena Governorates, estimate the current and economic containment capacity of this logistic service of The Packing and Cooling Station (HEIA) at Luxor,estimate the financial feasibility of (HEIA) at Luxor, sensitivity measurement analysis through three scenarios to find out the station's ability to meet operational capacity fluctuations and price risk, developing mechanisms to economically operate The station and finally, the direct and indirect impacts were assessed in case of the economic operation capacity of the Packing and Cooling Station (HEIA).

To achieve these objectives, the current study utilized questionnaires data at the level of nine associations dealing with the Project (Al-AMAL) during the season 2016/2017. Other information were from (HEIA) office data registers as well as information from some field and meetings obtained with parties who are concerned in this study. Analysis methods used the descriptive statistics of simple averages and percentages, SWOT analysis indicators, methods of quantitative analysis of financial feasibility study using the criteria of non-discount profitability and on discount profitability indicators.

Basic solution results were calculated at a capacity of 23.9 thousand tons annual production. The findings indicated that when the service fee is L.E. 1250.5 per ton; the internal rate of return for the project is estimated at about $23 \%$ greater than the alternative opportunity cost of capital. It was also noted that simple average return on investment is approximately $11.2 \%$ and the payback period of investment was estimated at 8.9 years. The breakeven point of production was estimated at about 22.8 tons per day, representing $26 \%$ of the operating capacity estimated at 88.1 tons per day. The previous results regarding the basic solution show that the minimum required to possibly operate the Station to yield cash flow should not be less than 23.9 thousand tons annually for a period of 270 days .

With the increase in the operating capacity mentioned in the first and second scenario by $21.3 \%, 63.2 \%$, respectively, from the operating capacity mentioned in the basic plan solution, the maximum fee per ton for scenario 1 , scenario 2 increases by $1.3 \%, 2.5 \%$, respectively, compared to the estimated L.E. 1250.5 service price fee per ton related to the basic plan solution. Meanwhile, the minimum price service fee per ton for scenario 1 and 2 decreases by $2.67 \%, 1.5 \%$, respectively, compared to the estimated L.E.1250.5 service price fee per ton in the basic plan solution.The third scenario decreases operating capacity by $17.5 \%$ from the operating capacity mentioned in the basic plan solution and reflected the results of economic inefficiency.
\end{abstract}


Operating the Cooling Station at its economic capacity requires coordination among all concerned parties from civil associations of farmers, the private sector of exporters, supermarkets and factories. A regulatory framework should be established based on contract farming development of horticultural crops providing technical support and post-harvest dealings for farmers.

Key words: Feasibility study, Sensitivity analysis, logistics service, Cooling and packing station, Associations, Horticultural export.

\section{INTRODUCTION}

Cold storage is considered the most important marketing service for the products of farmers, exporters and middlemen dealers with the marketing chains. Consequently, cold storage projects are important because they provide marketing services through sorting, grading and packing the crops (Berman,2002). Thus, it increases the marketing efficiency of agricultural products and reduces waste through transport, storage and controls of products flow to the markets at appropriate times to ensure satisfactory returns for producers. Cold storage does not only contribute in saving crops from damage but also maintains availability of fresh crops all year round for the local consumer.

The Horticultural Export Improvement Association (HEIA) used new investments worth L.E. 30 million total investments financed by USAID for improving the cooling station and its training center at Luxor Governorate in Upper Egypt with a storage capacity of 90 metric tons per day. Initial packing and cooling work at the station started July 2015.

The aim of establishing this logistics service is to support small stake holders and link them to higher value chains, export of fresh fruits and vegetables to targeted areas in Cairo and its vicinities. Furthermore, it nourishes the cooling station at Cairo Airport.

Operating the cooling station at its economic capacity, requires coordination among interested parties from farmers associations and the private sector exporters, supermarkets and factories. This requires a regulatory framework based on developing the process of horticultural crops farming contracts along with the provision of technical support and post-harvest activities to farmers, as well as implementing an arbitration system for quality linked to the price of horticultural crops produced and marketed. It also provides information and data to all parties dealing in contract farming to assist in decision making to achieve the objectives of all concerned parties.

\subsection{Problem of the article}

The Cooling and Packing Station affiliated to The Horticultural Export Improvement Association (HEIA) at Luxor Governorate is not functioning at its optimum capacity being 50 tons per day, as it only operates for no more than two months per year. The station's current operation is characterized by inefficiency. The station must operate for at least 10 months per year to reduce the operating costs, and consequently the service cost compared to the competitors.

This short operating cycle is due to the lack of horticultural crops optimizing the station's economic capacity. Furthermore, a negative situation is reflected by rising losses because of handling horticultural crops through traditional methods and the non-provision of exporters and marketing chains needs for products of quality in addition to job losses for the youth in Luxor Governorate.

\section{MATERIALS AND METHODS}

\subsection{The objectives}

The main objectives of this article were to study the actual status of horticultural crops production of associations at Luxor Governorate, determine current economic capacity for logistics service of the cooling and packing station at Luxor, estimate financial feasibility of The Cooling and Packing Station (HEIA) at Luxor and to estimate sensitivity analysis assessing the station's ability to meet operational capacities fluctuations and price risk, propose the economic operational methodology of The Cooling and Packing Station (HEIA), and finally assessment of the direct and indirect impacts when operating the station at its economic capacity.

\subsection{Data collection and analysis}

The data were based on a questionnaire used in nine associations dealing with the Project Advanced Marketing and Agribusiness Logistics (AMAL) during the season 2016/2017. The geographical scope of the nine studied associations included 5 districts described in Table (1). 
The data are information from the Association for the Development of Horticultural Crops (HEIA) Packing and Cooling Station at Luxor. This is in addition to some field reports and meetings with the managers of the cooling stations in the Governorates of Monoufia and Qena.

The study analysis depended on descriptive statistical methods of simple averages and percentages, SWOT analysis,quantitative analysis methods of financial feasibility study using the criteria of non-discount profitability, such as Break even point, the payback period and simple return on investment, profit analysis based on discount indicators such as net present value, cost-benefit ratio, internal rate of return and sensitivity analysis.

\section{RESULTS AND DISCUSSION}

\subsection{The actual situation of the associations of} horticultural production at Luxor Governorate

The present study relied primarily in this part on the questionnaire conducted in the surrounding productive areas of the associations provided with the logistical and technical support of AMAL Project. This reflected the productive and marketing status of Luxor Governorate according to the most important crops cultivated and marketed during the year 2016/2017. The productive status was examined for nine associations according to their geographical distribution districts at Luxor Governorate.

Table (1) indicates the reliance on one association at Luxor districtnamely "Altod Farmers Development Association". Its geographical zone is around 6000 feddans. It is located $18 \mathrm{~km}$ from HEIA Station. This is while "Qus"District comprises three associations namely: "Ahl Baladi Association", El Gad Elmoshrek Association "and El Amal el Tanmia El Shamla" with a geographical zone comprising $50,500,12$ feddan respectively. It is calculated by the distance parameter to be $15,15,25 \mathrm{~km}$ ,respectivelyfrom HEIA station. Meanwhile, "Armant District" represents two associations, namely "El Nesaea Association" and "Rowad Al Mostakbal" comprising 200 and 800 feddans, respectively. In terms of distance, the two associations are located $30,35 \mathrm{~km}$, respectively away from HEIA station. This is while the "Isna" District includes "Farsia Community Development " and " Ben Gedal
Society Development associations, representing 3000 and 4021 feddans respectively. In terms of distance, these associations are 60, $55 \mathrm{~km}$ respectively, away from (HEIA) station. Regarding "Al Waqf" District,"'Ganoub El Wadi Association" comprises 2560 feddans and is located, $100 \mathrm{~km}$ away from HEIA station.

Table (2) shows the marketing of vegetable production through local market, processed and export represent $93.2 \%, 3.7 \%$ and $3.1 \%$ of total estimated 188637 ton in 2016/2017. Also the same table shows the marketing of fruits production through local market, processed, export and supermarket represent $75.2 \%, 14 \%$ , $7.7 \%$ and $3.2 \%$ of total estimated 17905 ton in $2016 / 2017$. The total vegetables and fruits represented $91.3 \%$ and $8.7 \%$ from total horticultural 206542 tons during 2016/2017.

3.2. The current economic capacity for logistics service of the cooling and packing station((HEIA) at Luxor

This section deals with two parts . Frist, A description of the current operation potential of the cooling and packaging station of the Horticultural Export Improvement Association (HEIA). Second, Analysis of strengths, weaknesses, opportunities and threats of the packing and cooling station to identify all internal and external factors that caused the station not to operate at its economic capacity (https://www.businessnewsdaily.com/4245swot-analysis) .

Horticultural Export Improvement Association (HEIA) benefited from the investments of the USAID in Upper Egypt by establishing a cooling station with the capacity of 50 metric tons per day as investment cost 30 million pounds.

The activity was initialed on July 2015 . The primary objective was to promote the participation and the benefits to thousands of small holders in higher value chains as well as the export of fresh fruits and vegetables to targeted areas in Cairo and its vicinity providing likewise Cairo airport cooling station.

Horticultural Export Improvement Association (HEIA) has interest at the horticultural sector in Upper Egypt for the sector's tremendous opportunities to reach the profitable export markets. Land has been allocated in 2007 near Luxor national airport, less than $230 \mathrm{~km}$ from the Red Sea port of Safaga. 
Table (1): Distribution of horticultural production associations according to the area per feddan at Luxor and Qena Governorate Districts.

\begin{tabular}{|l|c|c|c|c|}
\hline $\begin{array}{l}\text { No of } \\
\text { Asso- } \\
\text { ciation }\end{array}$ & $\begin{array}{l}\text { The } \\
\text { District }\end{array}$ & Association Name & $\begin{array}{c}\text { The total cultivated } \\
\text { Area } \\
\text { per feddan }\end{array}$ & $\begin{array}{c}\text { Distance to HEIA } \\
\text { Station (km) }\end{array}$ \\
\hline 1 & Luxor & $\begin{array}{c}\text { "AltodFarmers Development" } \\
\text {-"El GhadElmoshrek" }\end{array}$ & 6000 & 18 \\
\hline 2 & Armant & El Nesaea & 200 & 30 \\
\hline 3 & Armant & Rowad Al Mostakbal & 800 & 35 \\
\hline 4 & Qus & El AmallelTanmia El Shamla & 12 & 25 \\
\hline 5 & Esna & Farsia Community Development & 3000 & 100 \\
\hline 6 & Al Waqf & Ganoub El Wadi & 2560 & 55 \\
\hline 7 & Esna & Ben Gedal Community Development & 4021 & 15 \\
\hline 8 & Qus & AhlBaladi & 50 & 15 \\
\hline 9 & Qus & El GhadElmoshrek & 500 & \\
\hline
\end{tabular}

Source:Questionnaires of Advanced Marketing and Agribusiness Logistics(AMAI) Project” at Luxor Governorate 2017

Table (2): The relative importance of horticultural crops under different marketing channels during the 2016/2017.

\begin{tabular}{|l|c|c|c|c|c|c|}
\hline $\begin{array}{c}\text { Marketing } \\
\text { channels }\end{array}$ & $\begin{array}{c}\text { Vegetables } \\
\text { ton }\end{array}$ & $\%$ & $\begin{array}{c}\text { Fruit } \\
\text { ton }\end{array}$ & $\%$ & $\begin{array}{c}\text { Total } \\
\text { horticultural } \\
\text { crops (ton) }\end{array}$ & $\%$ \\
\hline $\begin{array}{l}\text { Local } \\
\text { market }\end{array}$ & $\mathbf{1 7 5 8 4 9 . 7}$ & $\mathbf{9 3 . 2}$ & $\mathbf{1 3 4 6 3}$ & $\mathbf{7 5 . 2}$ & $\mathbf{1 8 9 3 1 2 . 7}$ & $\mathbf{9 1 . 7}$ \\
\hline Processed & $\mathbf{6 9 0 0}$ & $\mathbf{3 . 7}$ & $\mathbf{2 5 0 0}$ & $\mathbf{1 4 . 0}$ & $\mathbf{9 4 0 0}$ & $\mathbf{4 . 6}$ \\
\hline Export & $\mathbf{5 8 8 7 . 3}$ & $\mathbf{3 . 1}$ & $\mathbf{1 3 7 2}$ & $\mathbf{7 . 7}$ & $\mathbf{7 2 5 9 . 3}$ & $\mathbf{3 . 5}$ \\
\hline Supermarket & & & $\mathbf{5 7 0}$ & $\mathbf{3 . 1}$ & $\mathbf{5 7 0}$ & $\mathbf{0 . 2}$ \\
\hline Total & $\mathbf{1 8 8 6 3 7}$ & $\mathbf{1 0 0 . 0}$ & $\mathbf{1 7 9 0 5}$ & $\mathbf{1 0 0 . 0}$ & $\mathbf{2 0 6 5 4 2}$ & $\mathbf{1 0 0 . 0}$ \\
\hline
\end{tabular}

Source: Compiled and calculated from Tables (1 and 2) in Annex.

The storage capacity of the station is 90 metric tons per day of fresh goods of high quality. Project work plan outlines 244 days of work throughout the year with a particular focus on green beans (October), Strawberry (December and January), table grapes (May and June), pomegranate (August and September), watermelon (November and December). Other crops such as onions, garlic, Cherries, plums, tomatoes and sun-dried tomatoes will be considered. The cooling station goal is to increase the income of 4300 rural families in Upper Egypt including small farmers, landless workers, women, unemployed youth, small entrepreneurs and SMEs through their integration in high-value horticultural series ( heia Egypt.org).

The station will contribute to strengthening the capacities of farmers to organize and promote food security linking it to agricultural value chains to improve market access. It will enhance the ability of farmers to comprehend and respond to market signals and avail them to supply production for domestic and international markets by direct links with manufacturers and exporters expanding fresh products exported from Upper Egypt.
The researchers applied SWOT analysis to analyze the strengths, weaknesses, opportunities and threats of the station, in Table (3)

\subsection{The Financial Feasibility of the Packing and Cooling Station (HEIA) at Luxor}

The financial feasibility preparation for the Packing and Cooling Station (HEIA) at Luxor is based on determining the size of the horticultural crops raw material that could operate the station economically. The fixed operating costs are estimated on the basis of this magnitude of horticultural crops. Along the same lines, the price per ton for the pricing of the service to the station is calculated. Consequently, the preparation of the station's financial feasibility and the sensitivity measurement analysis reflecting the ability of the station to resist various types of special price risks as follows:

3.4 The size of the horticultural crops raw material that could operate the packing and cooling station

This section determines the economic capacity of the station according to the daily cooling capacity estimated at 50 tons / day and the number of days of operation by about 244 days, which depends on the total production of 
Table (3): SWOT analysis for the packing and cooling station at Luxor (HEIA).

\begin{tabular}{|c|c|}
\hline Strength & Opportunities \\
\hline $\begin{array}{l}\text { 1- Large storage capacity of } 90 \text { tons per day. } \\
\text { 2-The Station possession of excellent logistical } \\
\text { structure since it started operating in mid-July } \\
2015 \text {. } \\
\text { 3- Available finance for operation and maintenance. } \\
\text { 4-Offering training for administration } \\
\text { 5-Training Seasonal employment. } \\
\text { 6-Provide post-harvest technical support for } \\
\text { farmers. } \\
\text { 7- Helping horticultural farmers to export quality } \\
\text { certificates } \\
\text { 8- Assist farmers of local associations in developing a } \\
\text { database enabling them to take sound future } \\
\text { decisions. } \\
\text { 9- Comprehensive capacity building for local } \\
\text { exporters to reach regional and international } \\
\text { markets, } \\
\text { 10- creating jobs for youth and improve their } \\
\text { incomes }\end{array}$ & $\begin{array}{l}\text { 1- Good road networks } \\
\text { 2- The station is located on less than } 20 \mathrm{~km} \text { from } \\
\text { the Luxor airport } \\
\text { 3- The station is located on less than } 230 \mathrm{~km} \text { from } \\
\text { the sea port of Safaga. } \\
\text { 4- Close location to production areas } \\
\text { 5- Collaborate with Al AMAl Project in:- } \\
\text { - The Possibility to expand in horticultural crops } \\
\text { under existing farm planning contracts. } \\
\text { - Expansion in new horticultural production } \\
\text { demanded by exporters. } \\
\text { 6- Early production of horticultural crops makes } \\
\text { Luxor a hotspot where exporters can export to } \\
\text { foreign markets with less competitors. } \\
\text { 7- Supplying exporters and hotels, supermarkets } \\
\text { with desired crops. }\end{array}$ \\
\hline Weaknesses & Threats \\
\hline $\begin{array}{l}\text { 1- Work capacity for the packing and cooling station } \\
\text { during the } 40 \text { days grape season in May and June. } \\
\text { 2- The high cost of trained manpower. } \\
\text { 3- The high operating cost per ton under high labor, } \\
\text { energy and water costs. } \\
\text { 4- High fixed costs charged to the ton in case the non- } \\
\text { full capacity of The Station's operation. } \\
\text { 5- There is no fixed price for the service provided to } \\
\text { each source dealing with The Station pending } \\
\text { strength of connections with the management } \\
\text { association! }\end{array}$ & $\begin{array}{l}\text { 1-The existence of a packing station at" } \\
\text { "WadiNessim" in Isna District with a } 20 \text { ton/day } \\
\text { capacity, established in } 2010 \text { by CARE } \\
\text { International Organization. } \\
\text { 2-Competitors low prices for packing and } \\
\text { refrigeration services. } \\
\text { 3- Irregular electricity and water supply. } \\
\text { 4- The lack of trained manpower working - } \\
\text { 5- Higher prices of water and electricity } \\
\text { 6- The high rate of inflation. } \\
\text { 7- High taxe rates } \\
\text { 8 - The high cost of air freight . } \\
\text { 9- Low current quantities of horticultural crops } \\
\text { supplied to the station . } \\
\text { 10 -Low farmers' awareness of contract farming for } \\
\text { export . } \\
\text { 1-The problems among contracting entities and } \\
\text { associations in case any of the parties failure to } \\
\text { complete the contract. } \\
\text { 12. High market prices for crops over contract } \\
\text { prices. }\end{array}$ \\
\hline
\end{tabular}

Source: Horticultural Export Improvement Association (HEIA), meetings with field work team.

MUCIA , (2005)." Strengthening the Cold Chain in Upper Egypt - A Preliminary Study", AERI

https://www.businessnewsdaily.com/4245-swot-analysis https://heiaegypt.org

horticulture crops in Luxor and Qena Governorates during 2016/2017.

The financial feasibility estimation for the packing and cooling station requires determining the size of the raw material of 11 crops produced by nine associations at Qena and Luxor Governorates as reflected in Table (4). It was noted that $100 \%$ is absorbed from export crops of fruits and vegetables and about $10 \%$ of the volume of production is marketed locally. The estimated vegetables and fruits production is about 23.9 thousand tons per year, which economically operates the station.

It is noted from the same table that the contribution of vegetables and fruit crops for export as well as vegetables and fruit crops for the local market represent $24 \%, 5.7 \%, 64.7 \%$, $5.6 \%$ of the total estimated at 23976 tons during $2016 / 2017$. The daily production of horticultural crops is less than The station's containment capacity plant by at least 30 tons/day (implemented as the basis to operate the packing 
Table (4): The relative importance of horticultural crops per ton collaborating with the packing and cooling station (HEIA) according to the marketing channels ${ }^{1}$.

\begin{tabular}{|c|c|c|c|c|c|c|c|c|c|c|c|c|c|c|}
\hline The crop & 1. & 2. & 3. & 4. & 5. & 6. & 7. & 8. & 9. & 10. & 11. & 12. & Total & $\%$ \\
\hline $\begin{array}{l}\text { Vegetable } \\
\text { export }\end{array}$ & 1868.0 & 505.2 & 221.8 & 129.0 & & & & & & & 10.0 & 3030.2 & 5764 & 24.0 \\
\hline $\begin{array}{l}\text { Local } \\
\text { vegetable }\end{array}$ & 3392.7 & 3382.2 & 1744.5 & 445.8 & 49.0 & 43.3 & 41.5 & 44.0 & 122.8 & 173.2 & 1777.2 & 4280.7 & 15497 & 64.7 \\
\hline $\begin{array}{l}\text { Fruit } \\
\text { export }\end{array}$ & & & & 75.0 & 54.0 & 43.0 & & & & & 480.0 & 720.0 & 1372 & 5.7 \\
\hline $\begin{array}{l}\text { Fruit } \\
\text { Local. }\end{array}$ & & & & 12.0 & 421.6 & 351.7 & 111.0 & 47.0 & & & 180.0 & 220.0 & 1343 & 5.6 \\
\hline Total & 5261 & 3887 & 1966 & 662 & 525 & 438 & 153 & 91 & 123 & 173 & 2447.2 & 8250.9 & 23976 & 100 \\
\hline Tons/day & 169.7 & 102.3 & 63.4 & 22.1 & 16.9 & 14.6 & 4.9 & 2.9 & 4.1 & 5.6 & 81.6 & 266.2 & 65.7 & \\
\hline
\end{tabular}

1- Represents the total fruits and vegetables export wherein about $10 \%$ of the total vegetables and fruits is locally marketed-Source:Table(1 and 2) in Annex

and cooling station) during the seven months from April to October at a range between 2.9 22.1 tons/day. Meanwhile, the station's daily production capacity increases during the five months of January to March, November and December to a range about 63-266.2 tons/day

Table (5) indicates the horticultural crops marketed per month for export, where tomatoes and other crops represent $96 \%, 4 \%$ of the total estimated 1868 tons in January. Meanwhile, the tomatoes, pumpkin and other crops represent $58.6 \%, 35.3 \%, 6.1 \%$ respectively of total estimated 505 tons in February. Likewise, tomatoes, pumpkin and other crops represent $76.2 \%, 16.1 \%, 7.7 \%$, respectively, of the total estimated 222 tons in March. While the tomatoes and grapes represent $63.2 \%, 36.8 \%$ ,respectively, of the total estimated 204 tons in April. Meanwhile, grape represents $100 \%$ of the total estimated 54 tons in May, whereas the grape is $100 \%$ of the total estimated 43 tons in June.

The cantaloupe and green beans represent $98 \%, 2 \%$ of the total estimated 490 tons in November. Furthermore, tomatoes, cantaloupe and other crops represent $80 \%, 19.2 \%, 0.8 \%$, respectively, of the total estimated 3750 tons in December.

The same table refers to horticultural crops marketed per month for the local market to tomatoes and other crops $97.5 \%, 2.5 \%$, respectively, of the total estimated 3393 tons in January. Meanwhile, tomatoes and other crops represent $96.7 \%, 3.3 \%$ of the total estimated 3382 tons in February;while tomatoes and other crops represent $96.5 \%, 3.5 \%$ of the total estimated 1744 Ton in March.Likewise, the tomatoes, okra, zucchini and other crops represent $83.7 \%, 4.4 \%, 4.9 \%, 7 \%$ of the total estimated 458 tons in April.
While grapes, mangoes and other crops represent $57.1 \%, 32.5 \%, 10.4 \%$ of the total estimated 471 tons in May. Grapes, mangoes and okra represent $49.2 \%, 41.2 \%, 9.6 \%$ of the total estimated 389 tons in June. Likewise, mangoes, okra and other crops represent $66.2 \%$, $24.4 \%, 9.4 \%$ of the total estimated 153 tons in July. Mangoes, okra, zucchini and other crops represent $46.1 \%, 43.1 \%, 5.2 \%$, and $5.6 \%$ of the total estimated 91 tons in August. Tomatoes, pumpkin, okra and other cropsrepresent $48.8 \%$, $30.5 \%, 19.5 \%$, and $1.2 \%$ of the total estimated 123 tons in September. Meanwhile, tomatoes, zucchini ,pumpkin and okra represent $34.6 \%$, $32.2 \%, 21.6 \%, 11.6 \%$ of the total estimated 173 tons in October. In addition, tomatoes, cantaloupe and other crops represent $81 \%, 8.9$ $\%, 10.1 \%$, respectively, of the total estimated 2012 tons in November; while tomatoes, cantaloupe and other crops represent $92.4 \%, 4.9$ $\%, 2.7 \%$, respectively, of the total estimated 4504 tons in December.

\subsubsection{Cost assessment of the packing and cooling station}

The total costs of the packing and cooling station is divided into operating and variable costs. These costs have been estimated during 2016/2017. Table (6) indicates that the annual operating cost isitemized to comprise depreciation, permanent operating manpower, insurance, electricity, maintenance activities and emergencies representing $87.3 \%, 4.7 \%, 1.8 \%$, $2.1 \%, 2.1 \%, 2 \%$ of the total operating costs estimated to be L.E. 30.9 million. The per ton endurance ratio of these operating costs is about L.E.206.1, 343.5, 515.3 respectively.These are in view of the station's capacity being 50, 30, 20 tons per day. Its minimized operating capacity being 30,20 tons per day respectively leading to 
Table (5): Monthly horticultural crops production marketed per ton of the packing and cooling station (HEIA) 2016/2017

\begin{tabular}{|c|c|c|c|c|c|c|c|c|c|c|c|c|c|c|}
\hline The crop & $\begin{array}{l}\text { Marketing } \\
\text { channel }\end{array}$ & 1. & 2. & 3. & 4. & 5. & 6. & 7. & 8. & 9. & 10. & 11. & 12. & Total \\
\hline \multirow{3}{*}{$\begin{array}{c}\text { Green } \\
\text { Bean }\end{array}$} & Export & 17.8 & 12.3 & 2. & & & & & & & & 10. & 30.2 & 72.3 \\
\hline & Local. & 8.64 & 3.4 & 12.79 & 13.48 & & & & & & & 18.2 & 33.86 & 90.37 \\
\hline & Total & 26.44 & 15.7 & 14.79 & 13.48 & & & & & & & 28.2 & 64.06 & 162.67 \\
\hline \multirow{3}{*}{ Tomatoes } & Export & 1796 & 296 & 169 & 129 & & & & & & & & 3000 & 5390 \\
\hline & Local. & 3307 & 3272 & 1684 & 383 & 2.5 & & & & 60 & 60 & 1630 & 4182.5 & 14581 \\
\hline & Total & 5103 & 3568 & 1853 & 512 & 2.5 & & & & 60 & 60 & 1630 & 7182.5 & 19971 \\
\hline \multirow{3}{*}{$\begin{array}{l}\text { Green } \\
\text { onions }\end{array}$} & Export & & & & & & & & & & & & & \\
\hline & Local. & 40.2 & 56 & 14. & & & & & & & & 74 & 43.4 & 227.6 \\
\hline & Total & 40.2 & 56 & 14. & & & & & & & & 74 & 43.4 & 227.6 \\
\hline \multirow[t]{3}{*}{ Okra } & Export & & & & & & & & & & & & & \\
\hline & Local. & 6. & 6. & 3. & 20. & 24 & 37.2 & 37.2 & 39.2 & 24 & 20. & & & 216.6 \\
\hline & Total & 6. & 6. & 3. & 20. & 24 & 37.2 & 37.2 & 39.2 & 24 & 20. & & & 216.6 \\
\hline \multirow{3}{*}{ Pumpkin } & Export & 35.75 & 178.5 & 35.75 & & & & & & & & & & 250 \\
\hline & Local. & 1.67 & 6.66 & 1.67 & & & & & & 37.5 & 37.5 & & & 85 \\
\hline & Total & 37.42 & 185.16 & 37.42 & & & & & & 37.5 & 37.5 & & & 335 \\
\hline \multirow[t]{3}{*}{ Pepper } & Export & 18.4 & 18.4 & 15.0 & & & & & & & & & & 51.7 \\
\hline & Local. & 26.2 & 37.1 & 29.0 & 6.8 & & 6.1 & 4.3 & & & & & 17.9 & 127.3 \\
\hline & Total & 44.6 & 55.4 & 44.0 & 6.8 & & 6.1 & 4.3 & & & & & 17.9 & 179.1 \\
\hline \multirow[t]{3}{*}{ Zucchini } & Export & & & & & & & & & & & & & \\
\hline & Local. & 3 & 1 & & 22.5 & 22.5 & & & 4.8 & 1.3 & 55.7 & 55 & 3 & 165.8 \\
\hline & Total & 3 & 1 & & 22.5 & 22.5 & & & 4.8 & 1.3 & 55.7 & 55 & 3 & 165.8 \\
\hline \multirow[t]{3}{*}{ Grapes } & Export & & & & 75 & 54 & 43 & & & & & & & 172 \\
\hline & Local. & & & & 12. & 268.8 & 191.5 & 5. & & & & & & 477.3 \\
\hline & Total & & & & 87 & 322.8 & 234.5 & 5. & & & & & & 649.3 \\
\hline \multirow[t]{3}{*}{ Mango } & Export & & & & & & & & & & & & & \\
\hline & Local. & & & & & 152.8 & 160.2 & 101 & 42 & & & & & 456 \\
\hline & Total & & & & & 152.8 & 160.2 & 101 & 42 & & & & & 456 \\
\hline \multirow{3}{*}{ Cantaloupe } & Export & & & & & & & & & & & 480 & 720 & 1200 \\
\hline & Local. & & & & & & & & & & & 180 & 220 & 400 \\
\hline & Total & & & & & & & & & & & 660 & 940 & 1600 \\
\hline \multirow[t]{2}{*}{ Lemon } & Export & & & & & & & & & & & & & \\
\hline & Local. & & & & & & & 5 & 5 & & & & & 10 \\
\hline \multirow[t]{4}{*}{ Total } & Total & & & & & & & 5 & 5 & & & & & 10. \\
\hline & Export & 1868 & 505 & 222 & 204 & 54 & 43 & & & & & 490 & 3750 & 6964 \\
\hline & Local. & 3393 & 3383 & 1744 & 458 & 471 & 389 & 153 & 91 & 123 & 173 & 2012 & 4504 & 16997 \\
\hline & Total & 5261 & 3888 & 1966 & 662 & 525 & 438 & 153 & 91 & 123 & 173 & 2502 & 8254 & 23961 \\
\hline
\end{tabular}

1- Represents the total fruits locally marketed

Source: Questionnaires ,Advanced Marketing and Agribusiness Logistics “AMAl“ Project” at Luxor Governorate (2017).

and vegetables for export wherein about $10 \%$ of the total vegetablesand

Table (6): The operating cost items by One Thousand L.E. during 2016/2017.

\begin{tabular}{|l|c|c|}
\hline Cost items & $\begin{array}{c}\text { Thousands } \\
\text { LE }\end{array}$ & \% \\
\hline Depreciation & 2700.0 & 87.3 \\
\hline Employment Operations & 145.7 & 4.7 \\
\hline Insurance & 56.3 & 1.8 \\
\hline Electricity & 63.2 & 2.1 \\
\hline Maintenance works & 66.0 & 2.1 \\
\hline Emergencies & 60.6 & 2.0 \\
\hline Total & 30.019 & 100.0 \\
\hline Capplas
\end{tabular}

Capital costs 30 million EGP in (2015).

Source: Horticultural Export Improvement Association (HEIA) records -Luxor Governorate. the increased operating costs by $66 \%, 150 \%$ in comparison to the operating capacity of 50 tons per day.

Table (7) refers to the variable costs (excluding packages that it bears by the customer) per export ton for vegetable crops being about L.E. 696.4, 658.4, 697, 709.7, $694.4,694.4,694.4$ respectively; for each of green beans, tomatoes, green onions, okra, pumpkin, pepper, Zucchini. While, the cost per ton of export fruit crops is estimated to be L.E. $835.7,763.7,775.8,779$, respectively for each crop of grapes, mangoes, cantaloupe and lemon.

The average packing cost (excluding packages), cooling, freezing and other costs for the export vegetables estimated per ton to be 
Table (7): Estimating the variable costs for The Packing and Cooling Station of exportper LE/ ton during 2016/2017.

\begin{tabular}{|c|c|c|c|c|c|c|c|c|c|c|c|}
\hline Items & $\begin{array}{l}\text { Green } \\
\text { beans }\end{array}$ & $\begin{array}{c}\text { Tom } \\
\text { atoes }\end{array}$ & $\begin{array}{c}\text { Green } \\
\text { onions }\end{array}$ & Okra & $\underset{\text { kin }}{\text { Pump }}$ & Pepper & $\begin{array}{c}\text { Zucch } \\
\text { ini }\end{array}$ & $\begin{array}{c}\text { Grape } \\
\text { s }\end{array}$ & $\begin{array}{c}\text { Mang } \\
\text { o }\end{array}$ & $\begin{array}{c}\text { cantal } \\
\text { oupe }\end{array}$ & Lemon \\
\hline Cooling & 250 & 250 & 250 & 250 & 250 & 250 & 250 & 250 & 250 & 250 & 250 \\
\hline Packing & 552.5 & 500.5 & 556.25 & 574.6 & 552.5 & 552.5 & 552.5 & 656.5 & 552.5 & 570 & 574.6 \\
\hline Freezing & 80 & 80 & 80 & 80 & 80 & 80 & 80 & 120 & 120 & 120 & 120 \\
\hline Other & 120 & 120 & 120 & 120 & 120 & 120 & 120 & 180 & 180 & 180 & 180 \\
\hline Total & 1002.5 & 950.5 & 1006.3 & 1024.6 & 1002.5 & 1002.5 & 1002.5 & 1206.5 & 1102.5 & 1120.0 & 1124.6 \\
\hline $\begin{array}{l}\text { Total } \\
\text { without } \\
\text { packaging }\end{array}$ & 694.4 & 658.4 & 697.0 & 709.7 & 694.4 & 694.4 & 694.4 & 835.7 & 763.7 & 775.8 & 779.0 \\
\hline
\end{tabular}

Source: Horticultural Export Improvement Association (HEIA)records -Luxor Governorate and , data from a private packing station

about $36.0 \%, 35.1 \%, \quad 11.6 \%, 17.3 \%$ respectively, of the total estimated L.E. 691.8 per ton. While, the average packing costs (excluding packages), cooling, freezing and other costs for the export fruits per ton to be approximately $30.3 \%, 31.7 \%, 15.2 \%, 22.8 \%$ ,respectively, of the total estimated at L.E. 788.6 per ton.

Table (8) indicates that the variables cost (excluding packages that it bears by the customer) per ton marketed locally for vegetable crops are about L.E. 692, 656, 694, 707, 692, 692, 692 per ton for each of green beans, tomatoes, green onions, okra, pumpkin, peppers, zucchini respectively. Meanwhile, the cost per localton of fruit crops is estimated at L.E.565, $529,535,536$ per ton for each crop of grapes, mangoes, cantaloupe and lemon respectively.

The average packing costs (excluding packages) cooling, freezing and other costs for local vegetables is approximately $36.3 \%, 34.7$ $\%, 11.6 \%, 17.4 \%$,respectively, of the total estimated to be L.E. 689 per ton. Likewise, the average packing costs (excluding packages) cooling, freezing and other costs for local fruit per ton to be about $38.9 \%, 23.8 \%, 9.3 \%, 28 \%$, respectively, of the total estimated at L.E. 643 per ton.

Table (9) indicates that the Station fees comprises four items. The first item is the cost of cooling per export ton being LE 300. The packing cost ranges between L.E. 208.4 to 285.7 per ton depending on the nature of employment manpower, loss for each crop, freezing service fees estimated at L.E. 120, 180 per ton of vegetables and fruit respectively. The other expenses are estimated at L.E. 120,180 per ton of vegetables and fruit respectively.

Table (8): Estimating variable costs for the Packing and Cooling Station of the locally marketed L.E./ton during 2016/2017.

\begin{tabular}{|l|l|l|l|l|l|l|l|l|l|l|l|}
\hline \multicolumn{1}{|c|}{ Items } & $\begin{array}{l}\text { Green } \\
\text { beans }\end{array}$ & Tomatoes & $\begin{array}{c}\text { Green } \\
\text { onions }\end{array}$ & Okra & Pumpkin & Pepper & $\begin{array}{c}\text { Zucch } \\
\text { ini }\end{array}$ & Grapes & $\begin{array}{c}\text { Mango } \\
\begin{array}{c}\text { Can } \\
\text { talo } \\
\text { upe }\end{array}\end{array} \begin{array}{c}\text { Lemon } \\
\text { s }\end{array}$ \\
\hline Cooling & 250 & 250 & 250 & 250 & 250 & 250 & 250 & 250 & 250 & 250 & 250 \\
\hline Packing & 552.5 & 500.5 & 556.25 & 574.6 & 552.5 & 552.5 & 552.5 & 328.25 & 276.25 & 285 & 287.3 \\
\hline Freezing & 80 & 80 & 80 & 80 & 80 & 80 & 80 & 60 & 60 & 60 & 60 \\
\hline Other & 120 & 120 & 120 & 120 & 120 & 120 & 120 & 180 & 180 & 180 & 180 \\
\hline Total & 1002. & 950.5 & 1006.2 & 1024. & 1002.5 & 1002.5 & 1002. & 818.25 & 766.25 & 775 & 777.3 \\
\hline $\begin{array}{l}\text { Total } \\
\text { without } \\
\text { packaging }\end{array}$ & 692 & 656 & 694 & 707 & 692 & 692 & 692 & 565 & 529 & 535 & 536 \\
\hline
\end{tabular}

Source Table 7, data of Horticultural Export Improvement Association (HEIA) records (-Luxor governorate and , data from a private packing station. 
Table (9): Cost of services per L.E./ton for exported crops during 2016/2107.

\begin{tabular}{|l|l|l|l|l|l|l|l|l|l|l|l|}
\hline \multicolumn{1}{|c|}{ Items } & $\begin{array}{l}\text { Green } \\
\text { beans }\end{array}$ & $\begin{array}{c}\text { Tom- } \\
\text { atoes }\end{array}$ & $\begin{array}{c}\text { Green- } \\
\text { onions }\end{array}$ & Okra & $\begin{array}{c}\text { Pum- } \\
\text { pkin }\end{array}$ & $\begin{array}{c}\text { Pepp- } \\
\text { er }\end{array}$ & $\begin{array}{c}\text { Zucch- } \\
\text { ini }\end{array}$ & $\begin{array}{c}\text { Grap- } \\
\text { es }\end{array}$ & $\begin{array}{c}\text { Man- } \\
\text { go }\end{array}$ & $\begin{array}{c}\text { Canta } \\
\text { loupe }\end{array}$ & Lemons \\
\hline Cooling & 300 & 300 & 300 & 300 & 300 & 300 & 300 & 300 & 300 & 300 & 300 \\
\hline Packing & 244.4 & 208.4 & 246.95 & 259.7 & 244.4 & 244.4 & 244.4 & 285.7 & 213.7 & 225.8 & 229 \\
\hline Freezing & 120 & 120 & 120 & 120 & 120 & 120 & 120 & 180 & 180 & 180 & 180 \\
\hline Other & 120 & 120 & 120 & 120 & 120 & 120 & 120 & 180 & 180 & 180 & 180 \\
\hline Total & 784.4 & 748.4 & 786.95 & 799.7 & 784.4 & 784.4 & 784.4 & 945.7 & 873.7 & 885.8 & 889 \\
\hline
\end{tabular}

Source: Tables $(7,8)$.

Moreover,the cooling fee, the packing (excluding packages cost that it bears by the customer), , freezing and other expenses per ton of vegetables is about $38.4 \%, 31 \%, 15.3$ $\%, 15.3 \%$ respectively of the total estimated atL.E.781.8 per ton. While the cooling fee, the packing (excluding packages), the freezing and other expenses per fruit ton is about $33.4 \%, 26.5$ $\%, 20 \%, 20 \%$, respectively of the total estimated at L.E. 898.6 per ton.

It is worth mentioning that the final price per ton at the station includes fees plus $20 \%$ of the variable cost for the cooling and freezing services plus the station rental as an indicator of the management component being $12 \%$ of total operating costs (Swanberg et al.,2005).

\subsubsection{The estimation of the profitability indicators for the packing and cooling station:}

This part of the study uses some indicators to analyze how efficient the station is generating cash flow to cover costs and allow profitability. These indicators are the average return on investment (ROI), recovery period, and the breakeven point and internal rate on returns of the project. Also sensitivity analysis was conducted on the basis of assessing the station's capacity when facing circumstantial fluctuating pricing risks.

The basic solution was calculated on the basis of the station's capacity to absorb $10 \%$ of the total vegetables and fruits produced locally and $100 \%$ of the total exports of the same crops.

Table (10) indicates that operating the station with a capacity of 23.9 thousand tons per year generates a profit of L.E. 5.79 million at an average price of service being L.E. 1250.5 per ton. Meanwhile, the profits are assessed at about L.E. 4.59 million on the basis of the average price of the service being L.E. 1206.5 per ton.
The first scenario was calculated to increase the capacity of the station to absorb $15 \%$ of the total vegetables and fruits produced locally and $100 \%$ of the total exports of the same crops. The same table indicates that the station's operating capacity of 29 thousand tons per year generates a profit of L.E.7.67 million on the basis of the average price of the service being about L.E.1267 per ton. Meanwhile, the profits are assessed L.E. 6.20 million based on the service average price being L.E. 1217 per ton.

The second scenario was calculated to increase the capacity of the station to absorb 20 $\%$ of the total vegetables and fruits produced locally and $100 \%$ of the total exports of the same crops. The same table indicates that operating the Station at the capacity of 39 thousand tons per year generates a profit of L.E. 11.41 million at average price of service approximately L.E. 1283 per ton. Meanwhile, the profit is estimated by about L.E. 9.40 million based on the average price of the service being L.E. 1231.7 per ton.

The third scenario was calculated to dcrease the capacity of the station to absorb $7.5 \%$ of the total vegetables and fruits produced locally and $100 \%$ of the total exports of the same crops. The same table indicates that operating the Station at the capacity of 19.7 thousand tons per year generates a profit of L.E. 4.35 million at average price of service being L.E. 1227.6 per ton. Meanwhile, the profit estimated by about L.E. 3.05 million is based on the average price of the service at about L.E. 1161.5 per ton.

\subsubsection{Results of the financial feasibility for The Packing and Cooling Station}

The financial feasibility was estimated for the station based on ten years initiated at the beginning of the year 2016/2017. Table (11) indicates the basic solution of the station with an 
Table (10): Estimation of the total costs, income and annual profits by (1000 LE).

\begin{tabular}{|l|l|l|l|l|l|}
\hline & $\begin{array}{c}\text { The annual } \\
\text { production } \\
\text { capacity of the } \\
\text { station by } \\
\text { thousand tons }\end{array}$ & $\begin{array}{c}\text { Average price } \\
\text { Ton/L.E. }\end{array}$ & $\begin{array}{c}\text { Annual total costs } \\
\text { by thousand } \\
\text { pounds }\end{array}$ & $\begin{array}{c}\text { Annual total } \\
\text { income } \\
\text { by thousand } \\
\text { pounds }\end{array}$ & $\begin{array}{c}\text { Annual profit } \\
\text { By thousand } \\
\text { pounds }\end{array}$ \\
\hline \multirow{2}{*}{ Basic solution } & 23.9 & 1250.5 & 24216.6 & 30006.9 & 5790.4 \\
\cline { 2 - 6 } & 1206.5 & 24216.6 & 28806.7 & 4590.1 \\
\hline \multirow{2}{*}{ Scenario (1) } & \multirow{2}{*}{29.0} & 1267 & 29129.2 & 36802.7 & 7673.5 \\
\cline { 2 - 6 } & \multirow{2}{*}{ Scenario (2) } & 1217 & 29129.2 & 35330.6 & 6201.4 \\
\hline \multirow{2}{*}{ Scenario (3) } & \multirow{2}{*}{19.7} & 1283 & 38642.1 & 50051.4 & 11409.3 \\
\cline { 2 - 6 } & & 1227.6 & 38642.1 & 48049.4 & 9407.3 \\
\cline { 2 - 6 } & 1161.5 & 19842.0 & 24193.8 & 4351.8 \\
\hline \multirow{2}{*}{ S.0.7. } & 19842.0 & 22889.7 & 3047.8 \\
\hline
\end{tabular}

Source:Collected and calculated from Tables (5, 6, 7, 8 and 9).

annual capacity of 23.9 thousand tons and the price of the service at 1250.5 pounds per ton that the internal rate of return is estimated at about $23 \%$ greater than the alternate opportunity cost of capital. It is also noted that the simple average return on investment is approximately $11.2 \%$ and the payback period of investment is estimated at 8.9 years. The breakeven point is estimated at about 22.8 tons per day representing $26 \%$ of the operating capacity estimated at 88.1 tons per day.

When the ton fee is L.E. 1206.5, the project's internal rate of return is approximately $14 \%$, which is less than the alternative opportunity cost of capital. It is noted that simple average return on investment is approximately $6.8 \%$ and the payback period of investment is estimated at 14.6 year, the breakeven point was estimated at approximately 26.3 tons per day representing $30 \%$ of the operating capacity estimated at 88.1 tons per day.

\subsubsection{Sensitivity Analysis for the Packing and Cooling Station}

Table (11) points to the first scenario reflecting the annual production capacity being 29 thous and tons. The results according to a fee per ton being L.E. 1267 indicate that the internal rate of return for the project is estimated at $40 \%$ which is higher than the alternative opportunity cost of capital. It is also noted that simple average return on investment is approximately $19.5 \%$ and the payback period of investment is estimated at 5.1 years. The breakeven point was estimated at approximately 22.8 tons per day representing $21 \%$ of the operating capacity estimated at about 107.4 tons per day.

Also the results indicate that the fee per ton is at about L.E. 1217 reflecting any internal rate of return for the project estimated at $28 \%$ and is higher than the alternative opportunity cost of capital. It is noted that simple average return on investment of approximately $13.9 \%$ with payback period of investment estimated at around 7.19 years. The breakeven point is estimated at about 26.5 tons per day representing $25 \%$ of the operating capacity estimated to be about 107.4 tons per day.

The second scenario results reflect the annual production capacity of 39 thousand tons. According to the findings, and as per the L.E. 1283 ton fee, the internal rate of return for the project is estimated at $71 \%$ being higher than the alternative opportunity cost of capital. It is noted that the simple average return on investment is approximately $31.7 \%$ and the payback period of investment is estimated at 3.14 years. The breakeven point is estimated to be approximately 31.9 tons per day ,representing $22 \%$ of the operating capacity estimated at 144.4 tons per day.

Also the results show that the ton fee being L.E. 1231.7 reflects the project's internal rate of return to be about $51 \%$ increasing over the alternative opportunity cost of capital. It is noted that simple average return on investment is estimated at $24.4 \%$ and the payback period of investment is estimated at 4.1 years. The 
Table (11): Project profitability indicators based on discount

\begin{tabular}{|c|c|c|c|c|c|c|}
\hline & $\begin{array}{l}\text { Price } \\
\text { range } \\
\text { L.E./ton }\end{array}$ & $\begin{array}{l}\text { internal } \\
\text { rate of } \\
\text { return* } \\
\%\end{array}$ & $\begin{array}{l}\text { The } \\
\text { average } \\
\text { return on } \\
\text { investment* } \\
\%\end{array}$ & $\begin{array}{l}\text { Payback } \\
\text { period } \\
\text { Year } *\end{array}$ & $\begin{array}{l}\text { The } \\
\text { breakeven } \\
\text { production } \\
\text { point* } \\
\text { Tons/day }\end{array}$ & $\begin{array}{l}\text { Oppor } \\
\text {-tunity } \\
\text {-cost } \\
\%\end{array}$ \\
\hline \multirow{2}{*}{$\begin{array}{l}\text { Basic solution } \\
\text { Total exports and } 10 \% \text { of } \\
\text { the total local marketer }\end{array}$} & 1250.5 & 23 & 11.2 & 8.9 & 22.8 & 17 \\
\hline & 1206.5 & 14. & 6.8 & 14.6 & 26.3 & 17 \\
\hline \multirow{2}{*}{$\begin{array}{l}\text { Scenario (1) } \\
\text { Total exports and } 15 \\
\text { percent of the total local } \\
\text { marketer }\end{array}$} & 1267 & 40 & 19.5 & 5.1 & 22.8 & 17 \\
\hline & 1217 & 28 & 13.9 & 7.19 & 26.5 & 17 \\
\hline \multirow{2}{*}{$\begin{array}{l}\text { Scenario (2) } \\
\text { Total exports and } 20 \% \text { of } \\
\text { the total local marketer }\end{array}$} & 1283 & 71 & 31.7 & 3.14 & 31.9 & 17 \\
\hline & 1231.7 & 51 & 24.4 & 4.1 & 39.5 & 17 \\
\hline \multirow{2}{*}{$\begin{array}{l}\text { Scenario (3) } \\
\text { Total exports and } 7.5 \% \text { of } \\
\text { the total local marketer }\end{array}$} & 1227.6 & 12.0 & 5.9 & 16.83 & 20.7 & 17 \\
\hline & 1161.5 & 3.0 & 1.0 & 85.9 & 25.4 & 17 \\
\hline
\end{tabular}

*Estimate from equations 1,2,3 and 4 in Annex- Source: Table 10.

breakeven point is estimated at approximately 39.5 tons per day, representing $27 \%$ of operating capacity estimated at 144.4 tons per day.

The third scenario results reflect 19.7 thousand tons annual production capacity. According to the findings and as per the L.E. 1227.6 per ton fee, the total internal rate of return for the project is estimated at $12 \%$ which decreases in comparison to the alternative opportunity cost of capital. It is noted that simple average return on investment is around $5.9 \%$ and the payback period of investment is estimated at 16.83 years. The breakeven point is estimated approximately to be 20.7 tons per day representing $28 \%$ of the operating capacity estimated at 73 tons per day.

Also, the results indicative of the fee per ton being about L.E. 1161.5 did not realize any positive results. Consequently, the internal rate of return for the project is estimated at $3 \%$ with a decrease from the alternative opportunity cost of capital. It is noted that the simple average estimated return on investment is around $1 \%$ and the payback period of investment is estimated at about 85.9 years. The break even point is estimated at about 25.4 tons per day representing $35 \%$ of the operating capacity estimated at 73 tons per day. This means there is no service pricing for annual production capacity of station for the third scenario.
With the increase in the operating capacity of station for the first and second scenarios by $21.3 \%, 63.2 \%$ respectively from the operating capacity basic solution; the maximum fee per ton for the first scenario and the second scenario increases by $1.3 \%, 2.5 \%$ of the estimated fee per ton L.E. 1250.5 at the basic scenario. Meanwhile, the minimum fee per ton for scenario 1 and 2 decreases by $2.67 \%, 1.5 \%$ of the estimated L.E. 1250.5 fee per ton in the basic solution.

\subsection{Mechanism of operation of the Packing} and Cooling Station economically

The current situation of The Packing and Cooling Station depends on operating 1200 tons of grapes during 40 days. Consequently, The Station cash flow cannot be achieved despite the existence of surpluses of horticultural crops production of associations at Luxor and Qena Governorates. Thus, a flexible system should be developed permitting cooperation with associations and as same as with the private sector exporters and strength collaboration with local marketing chains.

\subsubsection{The station's operating mechanisms} depend on the following

1. Promotion of the cultivation contract between associations and the private sector which leads to stability in production volume that is selected on the basis of the contract price which must cover costs and allows a profit 
margin as well as reflecting changes in the prices of production factors and future production.

2. Solve problems arising between contracting parties through farmers awareness of the obligation to contract with other parties, regardless of market prices. The Association should plan to determine crop area contracted as a proportion of the total area.

3- Help the Association to obtain quality certificates for a rewarding rate and support private-sector confidence in the production of associations.

4- The provision of training courses by the station for associations in the field of technical support and post-harvest horticultural crops dealings for the purpose of expansion.

5- Provide information to exporters on associations willing to double areas for the cultivation of horticultural crops directed for export.

6- Assist the Association in providing information related to decision making related to the areas of horticultural crops cultivation.

7- Farmers awareness of the importance of operating the Station to provide employment opportunities for the youth in the region generating permanent income.

8- The selection of The Packing and Cooling Station (HEIA) to receive the raw material for the private sector.

9- Consider (HEIA) a neutral arbitration constituent between the associations and the private sector when determining the price of the product on the basis of the contract specifications and quality.

10- Setting Competitive pricing for a fee per ton at the Packing and cooling station.

11- Cooperation between the Station and Luxor airport to assist exporters using air transport.

3.6. Affected direct and indirect impacts in case of operating the Packing and Cooling Station at its economic capacity

1- The Packing and Cooling Station (HEIA) economic capacity makes it contain 23.9 thousand tons of fruits and vegetables annually wherein the export and local market share is about $29 \%, 71 \%$ respectively, from the total, yielding an annual total profit of 5.79 million EGP. This operating capacity gives an operational project internal rate of return at $23 \%$ which is higher than the alternative opportunity cost of capital $17 \%$.
The operating capacity of the Station is assessed to be 270 days with a capacity to create work opportunities by about 282 opportunities per year.

2- Services provided by the station for this production will maintain the quality of the product as well as the expand the period of validity for product which marketing local or international markets.

3- Operating the station at its economic capacity is a reflection of the success of contract farming for horticultural crops in the future. The contract system guarantees farmers a stable return and on the face guarantees exporters and private sector access to a quality product always.

4- The success of contract farming requires that the station provides a guiding role in agriculture and post-harvest to ensure high production quality required for contractors as well as the farmers receipt of the contract price. In addition, The station can prepare a trained agricultural advisor who can coach and deal efficiently with farmers.

5- The regular economic operation management of the Station is linked to contract farming which would create jobs during harvest seasons especially for export crops as well as availing jobs for regular transport service and the cooling transport service.

6- The role of The Station is very important in contract farming as it plays a judging role on quality specifications for horticultural crops enabling farmers ' to collect the contract price.

7- The associations declared the possibility to increase the volume of the export to the world markets, for most of the horticultural crops produced in the region by $50 \%$ from the current 2016/2017 status. This production is estimated by about 3.4 thousand tons on condition that the exporter and the finance are available. Expansion of this mode of production would maintain the economic capacity of the station and create new employment opportunities.

8- The Station can grant associations quality certificates allowing the farmers to join quality systems.

9- The station can negotiate with air and seaports to enjoy a preferential rate for exporters who deal regularly with the station conditioned by regular annual crop flow movement. 
Annex

Table (1): Monthly and daily available production for marketing of vegetable crops according to different marketing channels during the $2016 / 2017$.

\begin{tabular}{|c|c|c|c|c|c|c|c|c|c|c|c|c|c|}
\hline Month & 1. & 2. & 3. & 4. & 5. & 6. & 7. & 8. & 9. & 10. & 11. & 12. & Total \\
\hline $\begin{array}{l}\text { Local } \\
\text { market }\end{array}$ & 33188.1 & 34461.66 & 18704.6 & 16205.8 & 6090 & 910 & 443 & 392 & 1269 & 1269 & 17488 & 45424.6 & 175849.7 \\
\hline$\%$ & 18.9 & 19.6 & 10.6 & 9.2 & 3.5 & 0.5 & 0.3 & 0.2 & 0.7 & 0.7 & 9.9 & 25.8 & 100.0 \\
\hline Processed & 1600 & & & 5200 & & & & & & & & 100 & 6900 \\
\hline$\%$ & 23.2 & & & 75.4 & & & & & & & & 1.4 & 100.0 \\
\hline Export & 1813.8 & 308.3 & 171 & 419 & 135 & & & & & & 10. & 3030.2 & 5887.3 \\
\hline$\%$ & 30.8 & 5.2 & 2.9 & 7.1 & 2.3 & & & & & & 0.2 & 51.5 & 100.0 \\
\hline Total & 36601.9 & 34769.96 & 18875.6 & 21824.8 & 6225 & 910 & 443 & 392 & 1269 & 1269 & 17498 & 48554.8 & 188637 \\
\hline$\%$ & 19.4 & 18.4 & 10.0 & 11.6 & 3.3 & 0.5 & 0.2 & 0.2 & 0.7 & 0.7 & 9.3 & 25.7 & 100.0 \\
\hline $\begin{array}{l}\text { Daily } \\
\text { production }\end{array}$ & 1180.7 & 1199.0 & 608.9 & 727.5 & 200.8 & 29.4 & 14.8 & 12.6 & 42.3 & 40.9 & 583.3 & 1566.3 & 515.4 \\
\hline
\end{tabular}

Source: compiled and calculated from questionnaires for Private Associations in Luxor and Qena, Advanced Marketing and Agribusiness Logistics (AMAl ) Project (2017).

Table (2): Monthly and daily available production for marketing of fruit crops according to different marketing channels during the 2016/2017.

\begin{tabular}{|l|l|l|l|l|l|l|l|l|l|l|l|l|l|}
\hline Month & $\mathbf{1 .}$ & $\mathbf{2 .}$ & $\mathbf{3 .}$ & $\mathbf{4 .}$ & $\mathbf{5 .}$ & $\mathbf{6 .}$ & $\mathbf{7 .}$ & $\mathbf{8 .}$ & $\mathbf{9 .}$ & $\mathbf{1 0 .}$ & $\mathbf{1 1 .}$ & $\mathbf{1 2 .}$ & Total \\
\hline Local market & 900 & 80 & 40 & 150 & 2698 & 3443 & 1662 & 1070 & 380 & 2100 & & 1030 & 13463 \\
\hline \% & 6.7 & 0.6 & 0.3 & 1.1 & 20.0 & 25.6 & 12.3 & 7.9 & 2.8 & 15.6 & & 7.7 & 100.0 \\
\hline Processed & & & & & & & 50 & & 50 & & 1230 & 1170 & 2500 \\
\hline \% & & & & & & & 2. & & 2. & & 49.2 & 46.8 & 100 \\
\hline Export & & & & 75 & 54 & 43 & 10. & & & & 480 & 720 & 1372 \\
\hline \% & & & & 5.5 & 3.9 & 3.1 & 0.7 & & & & 35.0 & 52.5 & 010 \\
\hline Supermarket & & & & & & & & & & & 570 & & 570 \\
\hline \% & & & & & & & & & & & 100 & & 100 \\
\hline Total & 900 & 80 & 40 & 225 & 2752 & 3486 & 1722 & 1070 & 430 & 2100 & 2280 & 2920 & 17905 \\
\hline \% & 5.0 & 0.4 & 0.2 & 1.3 & 15.4 & 19.5 & 9.6 & 6.0 & 2.4 & 11.7 & 12.7 & 16.3 & 100.0 \\
\hline $\begin{array}{l}\text { Daily } \\
\text { production }\end{array}$ & 29.0 & 2.8 & 1.3 & 7.5 & 88.8 & 112.5 & 57.4 & 34.5 & 14.3 & 67.7 & 76.0 & 94.2 & 48.9 \\
\hline
\end{tabular}

Source: compiled and calculated from questionnaires for Private Associations in Luxor and Qena, Advanced Marketing and Agribusiness Logistics (AMAl ) Project(2017).

\section{Financial analysis*:-}

1- $\quad$ Undiscounted measures:-

Payback Period=capital investment/ net cash flow of project (1)

Simple Rate of return $=$ net average cash flow / invested capital (2)

Break-Even analysis $=$ total fixed cost/ price of production - average variable cost (3)

2- $\quad$ Discounted measures:

$\mathrm{IRR}=\mathrm{r} 1+\left((\mathrm{r} 2-\mathrm{r} 1)^{*}(\mathrm{NPV} 1 \backslash(\mathrm{NPV} 1-\mathrm{NPV} 2))\right.$

IRR= Internal Rate of Return

$\mathrm{r} 1=$ minimum discount rate

r2= maximum discount rate

$\mathrm{NPV} 1=$ net present value at minimum discount rate

$\mathrm{NPV} 2=$ net present value at maximum discount rate

* Gittinger (1982). 


\section{REFERENCES}

Advanced Marketing and Agribusiness Logistics ( AMAL) (2017).Office data records

Berman E.(2002). "Marketing" Atomic Dog publishing .

Field interviews with the managers of cooling stations in the governorates of Monoufia and Qena, (2017).

Gittinger J. P. (1982). “ Economic analysis of agricultural projects “, The Johns Hopkins University press, Baltimore and London, second edition.
Horticultural Export Improvement Association (2017).Office data from the records.

Questionnaire for Private Associations in Luxor and Qena ,(2017).

MUCIA (2005)." Strengthening the Cold Chain in Upper Egypt-A Preliminary Study", AERI Institutional Linkage Project .

Swanberg K. and Abdul-Aziz A. (2005). "Horticulture Post Harvest Centers in upper Egypt ", Agricultural Exports and Rural Incomes (AERI).

https://www.businessnewsdaily.com/4245-swotanalysis https://heiaegypt.org

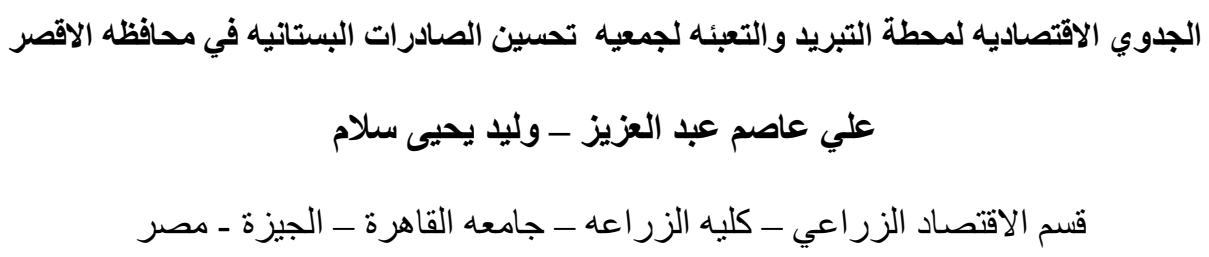

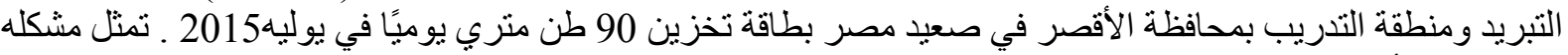

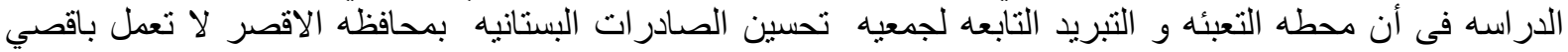

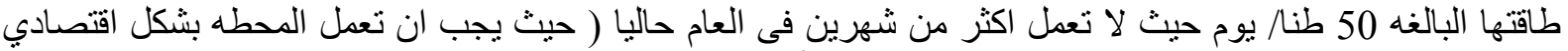

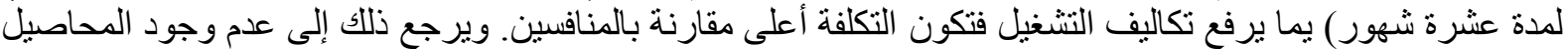

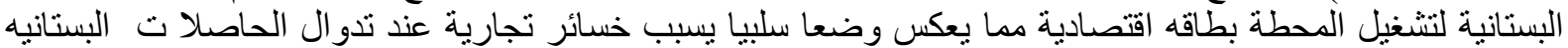

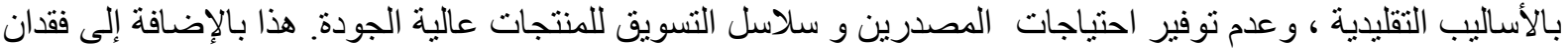

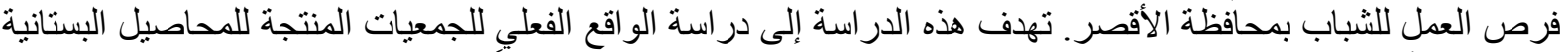

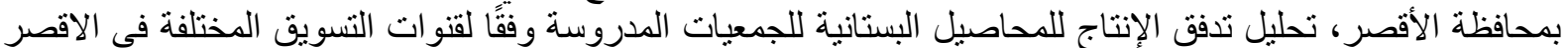

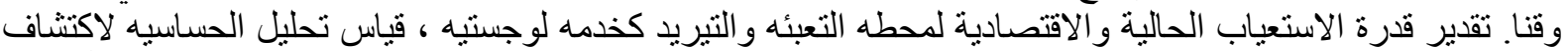

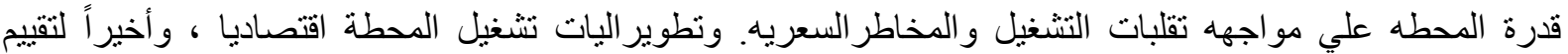

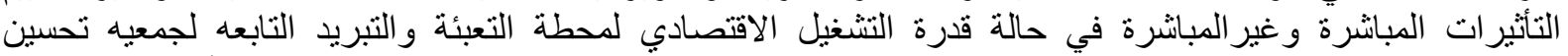

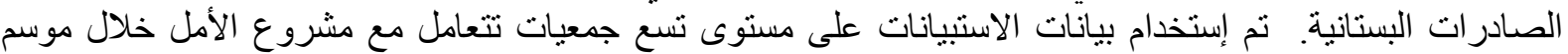

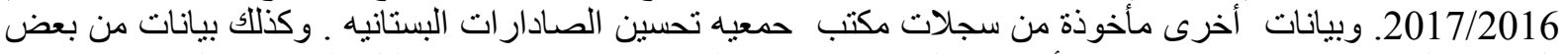

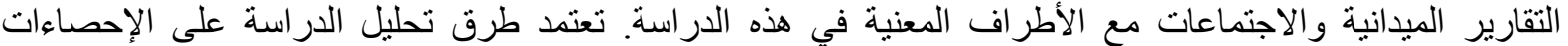

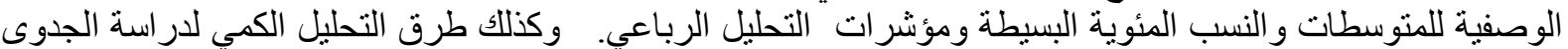

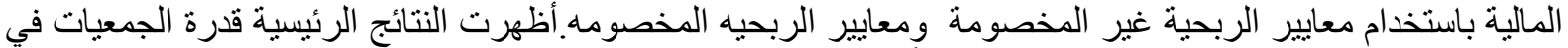

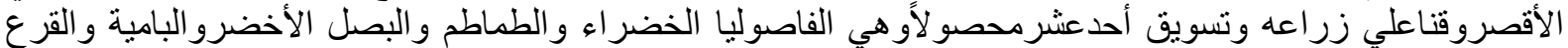

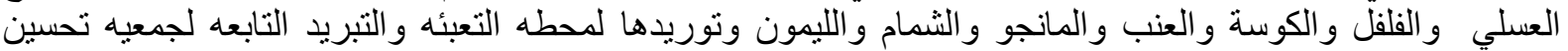

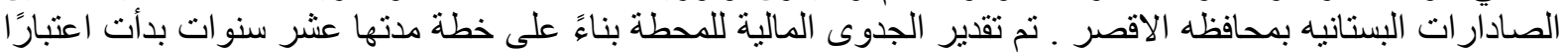

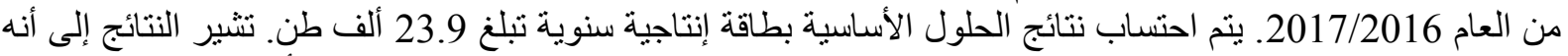

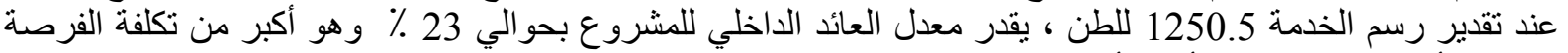

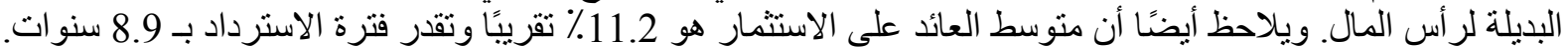

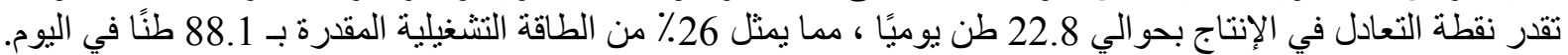

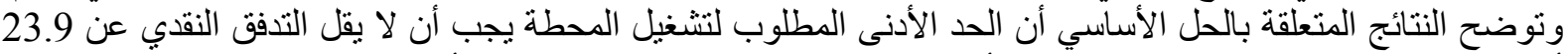

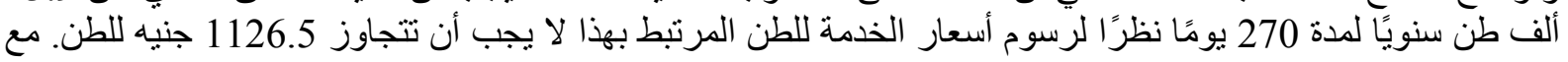




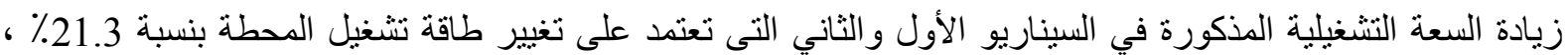

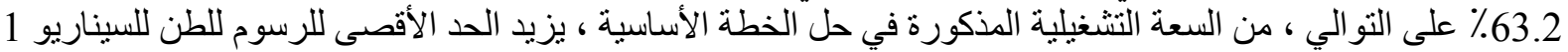

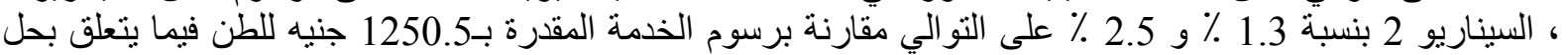

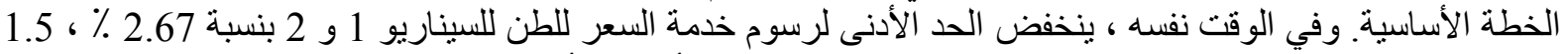

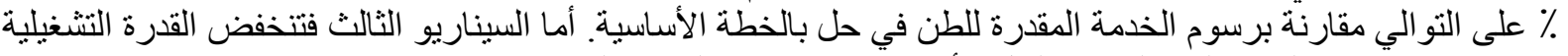

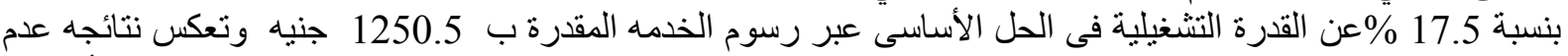

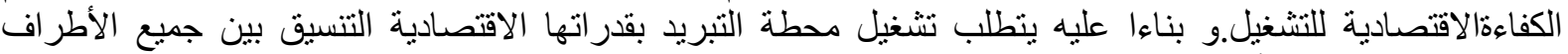

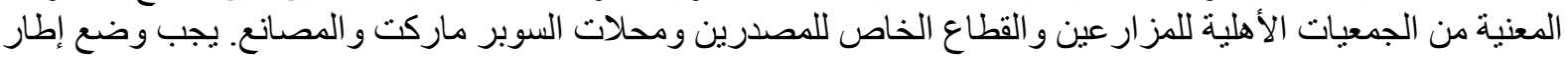

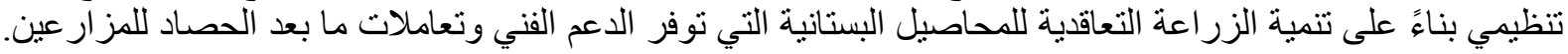
وتطبيق نظام تحكيم للجودة يربطه بسعر الزبة المحاصيل.

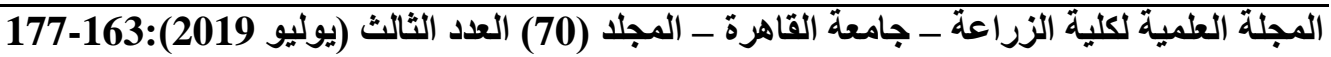

